Gut, 1988, 29, 1370-1378

\title{
Radioautographic localisation of iodinated human intrinsic factor in the guinea pig ileum using electron microscopy
}

\author{
J L GUÉANT, A GÉRARD, B MONIN, B CHAMPIGNEULle, H GÉRARD, \\ AND J P NICOLAS
}

From Unité INSERM U 308, Equipe de Biochimie-Immunologie and Laboratoire d'Histologie-Embryologie Faculté de Médecine B, Université de Nancy I, Vandoeuvre-les-Nancy Cedex, France

SUMmaRY The uptake of iodinated human intrinsic factor by guinea pig ileum was studied in vivo using electron microscopy radioautography. Iodination of intrinsic factor cobalamin complex with $\mathbf{N}$-chlorobenzene-sulphonamide beads did not modify its physicochemical properties in gel filtration, nor in iso-electrofocusing. It didn't affect its biological activity either in vitro in presence of solubilised receptor, or in vivo in the Schilling test. The ${ }^{125}$ I-intrinsic factor cobalamin complex was instilled in vivo in ileal blind loops in presence of either $\mathrm{CaCl}_{2}, \mathrm{EDTA}$, bile or intestinal juice. The labelled complex was predominantly located in the intermicrovillous pits of the apical membrane and in the apical cytoplasm. The uptake was about five-fold lower in presence of EDTA. On the apical membrane, the number of grains (per $80 \mu \mathrm{m}$ length of epithelium) increased from $2 \cdot 7(0 \cdot 2)$ up to $9.4(1.7)$ respectively for 15 minutes and two hours of delay. This suggests a recycling of the intrinsic factor receptor complex. In the apical compartment, the silver grains were often detected over non-coated vesicles and over the infoldings of the lateral membrane. These results show that intrinsic factor is internalised into enterocytes during cobalamin absorption, and that a part of intrinsic factor enters the blood circulation through transcytosis.

The absorption of cobalamin needs its binding to a glycoprotein secreted by the stomach, the intrinsic factor (IF) and the subsequent calcium dependent binding of the Cbl-IF complex to a specific ileal receptor. The number of ileal IF receptors is restricted. ${ }^{1-}$ It has been shown that $\mathrm{Cbl}$ enters the enterocytes in less than one hour ${ }^{5}$ but the mechanism of the transfer has not yet been elucidated. The enterocyte subcellular distribution of the labelled $\mathrm{Cbl}$ orally administered to guinea pigs ${ }^{6}$ or dogs' $^{7}$ showed the presence of the vitamin in the lysosomes of enterocytes after two hours.

Contrary to that of $\mathrm{Cbl}$, the fate of IF remains debatable. ${ }^{*}$ Several recent findings suggest that IF is internalised into the enterocytes in the guinea pig (i) after incubation of ${ }^{35} \mathrm{~S}$-methionine labelled rabbit IF

Address for correspondence: Dr J L. Guéant and Professor J P Nicolas. Unité Inserm U 308. Faculté de Médecine. BP 184, 54505 Vandoeuvre-les-Nancy Cedex. France.

Received for publication 9 May 1988 with isolated guinea pig ileal enterocytes for periods of up to 30 minutes, only half of the radioactivity was removed by washing the cell surface with acid or EDTA; (ii) [ $\left.{ }^{125} \mathrm{I}\right]$-iodinated IF was localised in lysosomes, brush border membrane, and cytosol of guinea pig ileum maintained in organ culture.' The internalisation of IF has also been observed in rabbit ileal explants."

Other findings suggested that only $\mathrm{Cbl}$, but not IF, enters the cell. Hines and coworkers observed on everted sac of guinea pig ileum that the permeasic activity of IF for $\mathrm{Cbl}$ was maintained after sequential incubations with labelled Cbl." Finally, a morphological investigation using immunocytochemical localisation of IF found the molecule associated only with the microvillous pits of enterocytes from guinea pig ileum. ${ }^{+}$In the present work, we have studied the fate of IF after its binding to ileal mucosa in the guinea pig in vivo, using high resolution electron microscopy radioautography instead of immunocytochemistry. 
Methods

\section{CHEMICALS}

[125I]-iodine (1 Ci/67 $\mu \mathrm{mol})$ was obtained from the radiochemical Centre (Amersham, England). Iodo beads $^{\mathrm{TM}}$ were purchased from Pierce (Rockford, USA) and Sephacryl S 300 from Pharmacia Fine Chemicals (Uppsala, Sweden). Other reagents were obtained as described elsewhere. ${ }^{113}$

\section{IODINATION OF INTRINSIC FACTOR}

Intrinsic factor was purified from human gastric juice as recently described. ${ }^{11}$ One nanomole IF was iodinated using the method of Markwell et al. ${ }^{12}$

Iodo beads were incubated at room temperature with $100 \mu \mathrm{Ci}$ of [ ${ }^{125} \mathrm{I}$ ]-iodine in $200 \mu \mathrm{l} 20 \mathrm{mM}$ Tris $\mathrm{HCl}$ pH 8.0 during five minutes. Two nanomoles of IF-Cbl complex were then added in a total volume of $400 \mu$ l $20 \mathrm{mM}$ Tris $\mathrm{HCl}$ buffer $\mathrm{pH} \mathrm{8.0.} \mathrm{After} 15$ minutes of incubation, the beads were discarded and $200 \mu \mathrm{l}$ of $20 \mathrm{mM}$ Tris $\mathrm{HCl}$ buffer $\mathrm{pH} 8 \cdot 0$ containing $0 \cdot 125 \mathrm{NaCl}$ and $2 \%(\mathrm{wt} / \mathrm{vol})$ of potassium iodide was added. The incubation mixture was poured onto a Sephacryl S 300 column dimensioned $1 \times 40 \mathrm{~cm}$, filtered with 20 mM Tris $\mathrm{HCl}$ buffer $\mathrm{pH} 8.0$ containing $0.5 \mathrm{M} \mathrm{NaCl}$, $2 \%(\mathrm{wt} / \mathrm{vol})$ of potassium iodide, and $0.2 \%$ (wt/vol) bovine serum albumin at a flow rate of $0.2 \mathrm{ml} / \mathrm{min}$.

Dextran Blue 2000 and tritiated water were used to calibrate the column. The molecular mass of the iodinated IF ([ $\left.\left.{ }^{125} I\right]-I F\right)$ was estimated using labelled human serum albumin and IgG as described previously. ${ }^{13}$

A part of the pooled fraction of [ $\left.{ }^{125} \mathrm{I}\right]-\mathrm{IF}-\mathrm{Cbl}$ was poured onto a $110 \mathrm{ml} \mathrm{LKB}$ isoelectrofocusing column packed with carrier ampholytes of $\mathrm{pH} \mathrm{2 \cdot 5-4.0}$ and of pH 3.5-6.0 in a final concentration of $1 \%$ and in a $0-50 \%$ (wt/vol) sucrose gradient.

\section{BIOLOGICAL ACTIVITY OF THE IODINATED}

\section{INTRINSIC FACTOR}

[ ${ }^{125}$ I]-IF was tested in vitro in presence of a solubilised IF receptor extract. The receptor extract was prepared from guinea pig ileal mucosa after the method of Kouvonen et al..$^{14}$ About $0.04 \mathrm{nmol}$ of [ [25 I]-IF-Cbl was incubated with $0.8 \mathrm{ml}$ of the receptor extract in presence of either $1 \mathrm{mM} \mathrm{CaCl}$ or $1 \mathrm{mM}$ EDTA in a total volume of $1 \mathrm{ml}$. Each incubation mixture was then poured onto a Sephacryl column dimensioned $2.5 \times 100 \mathrm{~cm}$ filtered with $20 \mathrm{mM}$ Tris $\mathrm{HCl}$ buffer $\mathrm{pH}$ 8.0 containing $0.5 \mathrm{M} \mathrm{NaCl}$ and $1 \mathrm{mM} \mathrm{CaCl}$ at a flow rate of $30 \mathrm{ml} / \mathrm{h}$. The ability of iodinated IF-Cbl complex to be degraded was also tested by incubating 0.04 nmoles of [ $\left.{ }^{125} \mathrm{I}\right]-\mathrm{IF}-\mathrm{Cbl}$ with $20 \mu \mathrm{l}$ ileal guinea pig intestinal juice in a total volume of $1 \mathrm{ml} 20 \mathrm{mM}$ Tris $\mathrm{HCl}$ buffer $\mathrm{pH} 8.0$ containing $0.5 \mathrm{NaCl}$ and $1 \mathrm{mM}$ $\mathrm{CaCl}_{2}$, during one hour at room temperature. The sample was then filtered as described above. The in vivo biological activity of IF iodinated with nonisotopic iodide was also tested by a Schilling test in an Addison Biermer anaemia patient.

IN VIVO GUINEA PIG INCUBATIONS

The experiments were carried out as described by Levine et al. ${ }^{4}$ Nine fasted male guinea pigs were anaesthetised with pentobarbital ( $25 \mathrm{mg} / \mathrm{kg}$ ip). After laparotomy, three $1 \mathrm{~cm}$ ileal loops were made by three double ligatures of the terminal ileum per animal. The border circulation was carefully pre-
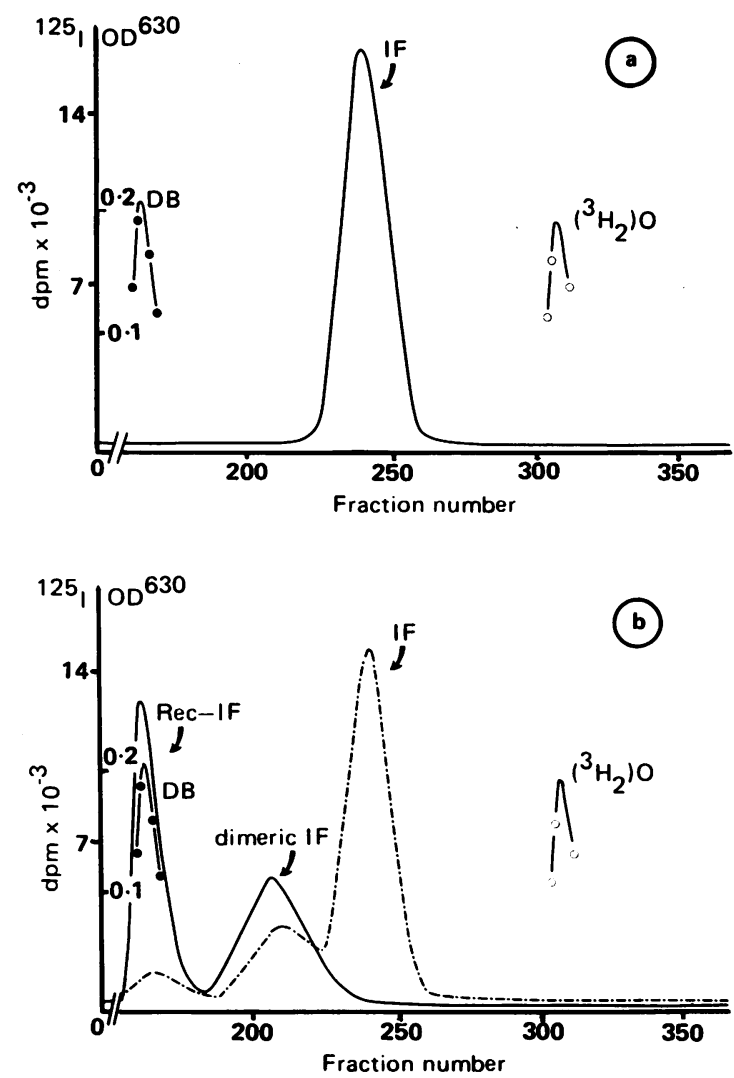

Fig. 1 (a) Elution profile of the iodinated human intrinsic factor cobalamin complex ([25I]-IF-Cbl) in Sephacryl S 300 gel filtration. The [125I]-IF-Cbl complex was eluted in a position corresponding to a molecular mass of about 50000 daltons. (b) In presence of ileal intrinsic factor receptor extract from guinea pig and of $1 \mathrm{mM} \mathrm{CaCl}{ }_{2}$, the $\left[{ }^{125} I\right]-I F-C b l$ was eluted in the same position as dextran blue (DB) corresponding to its binding to the receptor (-). This phenomenon was not observed when 1 mM EDTA was added in the incubation mixture instead of $\mathrm{CaCl}_{2}(-\cdot-)$; in that case, IF was eluted as a monomer and a dimer. 


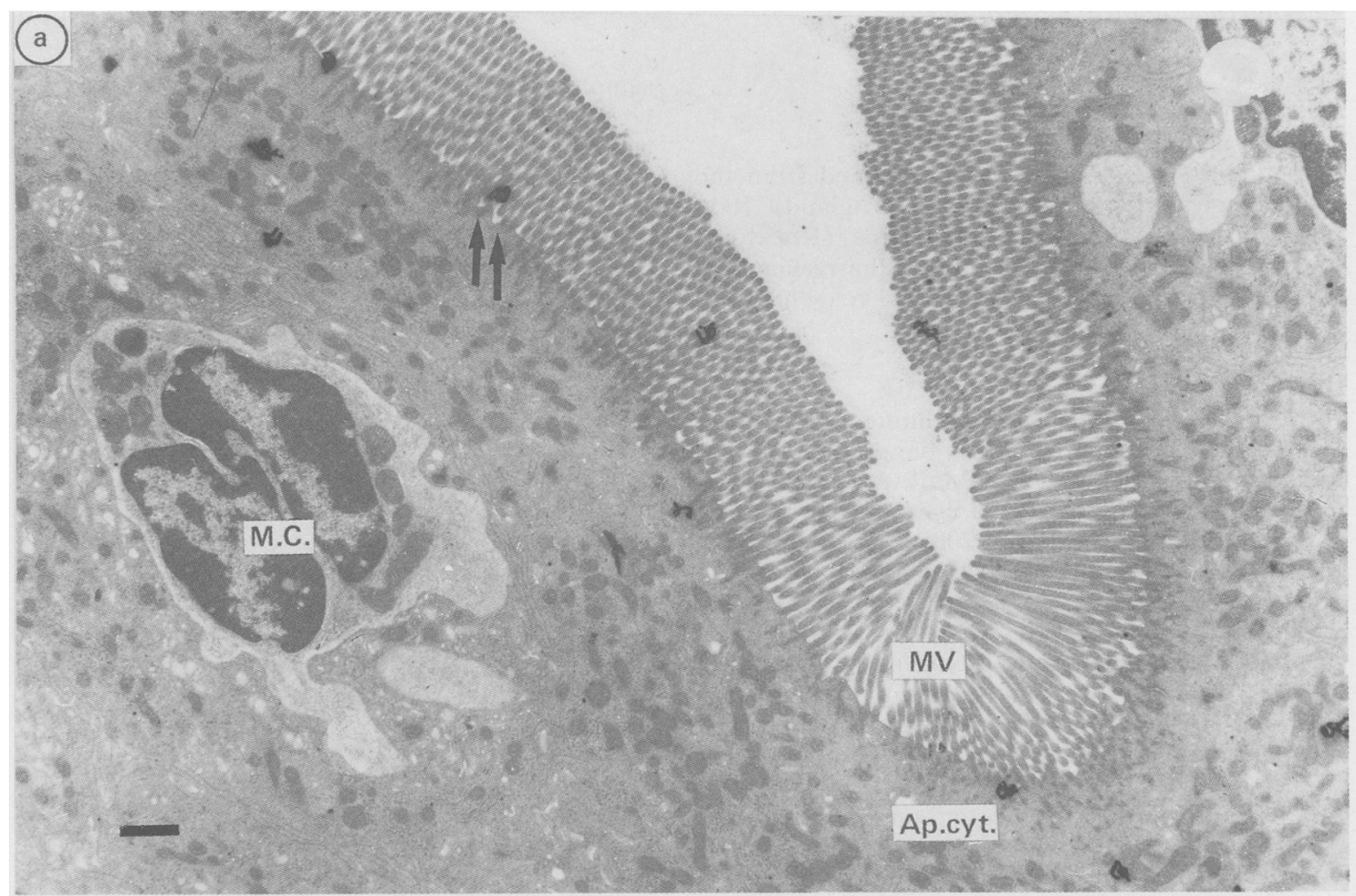

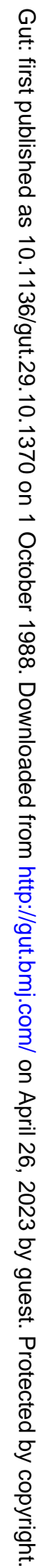

(b)

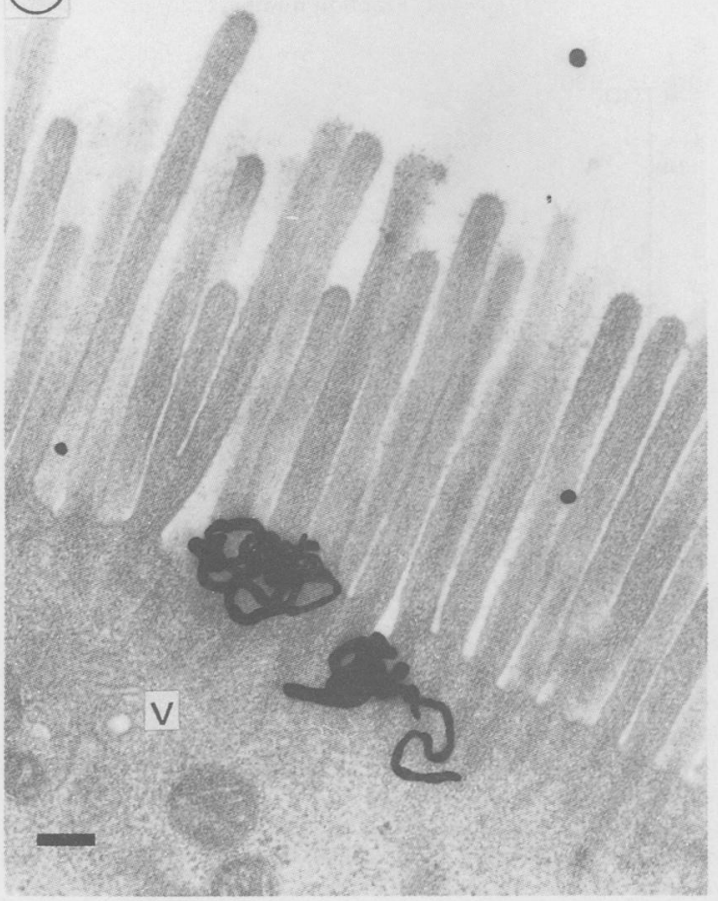

(c)

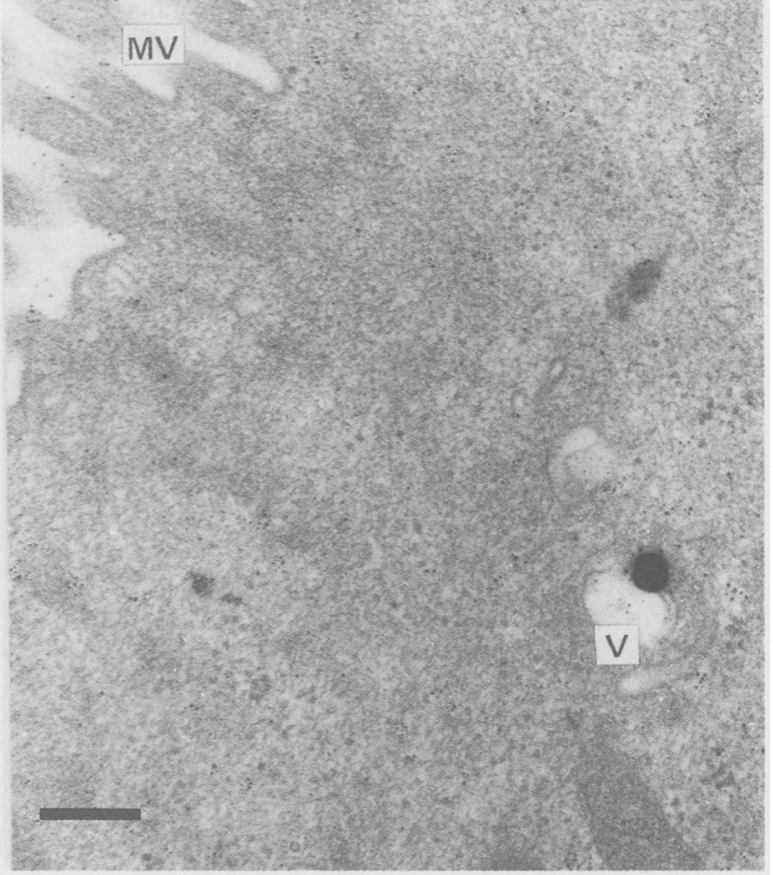

Fig. 2a, b, c. 
Table 1 Distribution of iodinated intrinsic factor-cobalamin complex ( $\left.{ }^{12} I-I F-C b l\right)$ in the enterocytes of guinea pig ileum using radioautography

\begin{tabular}{|c|c|c|c|c|c|c|c|}
\hline \multirow[b]{2}{*}{ Instilled sample } & \multirow[b]{2}{*}{$\begin{array}{l}\text { Incubation } \\
\text { time (min) }\end{array}$} & \multirow[b]{2}{*}{ Analyses (n) } & \multicolumn{5}{|c|}{ Grains $/ 80 \mu m$ length of epithelium $(n)$} \\
\hline & & & Total & Microvilli & $\begin{array}{l}\text { Apical } \\
\text { cytoplasm }\end{array}$ & $\begin{array}{l}\text { Basal } \\
\text { cytoplasm }\end{array}$ & Nucleus \\
\hline$[\because \mathrm{I}]-\mathrm{IF}-\mathrm{Cbl}+\mathrm{SPB}$ & 15 & 3 & $8 \cdot 3(3 \cdot 0)$ & $2 \cdot 7(0 \cdot 2)$ & $4 \cdot 7(0 \cdot 4)$ & $0 \cdot 4(0 \cdot 2)$ & $0 \cdot 3(0 \cdot 2)$ \\
\hline$[\because I]-I F-C b]+S P B$ & 120 & 6 & $21 \cdot 4(12 \cdot 3)$ & $9.4(1.7)$ & $8 \cdot 3(2 \cdot 1)$ & $1 \cdot 3(0 \cdot 6)$ & $2 \cdot 1(0 \cdot 6)$ \\
\hline$[\because] \mid-[F-C b]+K B$ & 120 & 3 & $20 \cdot 6(5 \cdot 1)$ & $9 \cdot 5(0 \cdot 6)$ & $7 \cdot 4(2 \cdot 5)$ & $1 \cdot 2(1 \cdot 0)$ & $2 \cdot 5(1 \cdot 0)$ \\
\hline ['I]-IF-CbI+Bile & 120 & 3 & $13 \cdot 4(5 \cdot 2)$ & $5 \cdot(0(0 \cdot 4)$ & $6 \cdot 2(0 \cdot 7)$ & $1 \cdot 1(0 \cdot 5)$ & $1 \cdot 2(0 \cdot 1)$ \\
\hline$[\because 2 I]-I F-C b l+E D T A$ & 120 & 3 & $4 \cdot 9(4 \cdot 7)$ & $1.4(0.7)$ & $1 \cdot 6(0 \cdot 2)$ & $0 \cdot 8(0 \cdot 3)$ & $1 \cdot 1(0 \cdot 4)$ \\
\hline
\end{tabular}

$0.02 \mathrm{nmol}$ ['25I]-IF-Cbl complex was instilled in vivo in ileum in each experiment. The scoring of the grains of each cell compartment was calculated from the determination of the distribution of grains in each compartment and the average of total grains detected over $80 \mu \mathrm{m}$ length of epithelium. SPB: sodium phosphate buffer; KB: Krebs buffer; IF: intestinal juice; EDTA: ethylenediaminetetraacetic acid.

served from the ligatures. One hundred microlitres $0 \cdot 1 \mathrm{M}$ sodium phosphate buffer $\mathrm{pH} 7 \cdot 4$ containing $0 \cdot 15 \mathrm{NaCl}, 1.5 \mathrm{mM} \mathrm{CaCl}{ }_{2}$ and $0.02 \mathrm{nmol}$ of the ['is]IF-Cbl complex $(0 \cdot 18 \mu \mathrm{Ci})$ was instilled in each loop by means of a needle. In two other series of experiments, the $\left[{ }^{125} \mathrm{I}\right]-\mathrm{IF}-\mathrm{Cbl}$ complex was instilled with $100 \mu \mathrm{l}$ bile or of human duodenal juice instead of sodium phosphate buffer. After 15 minutes or two hours of incubation the loops were excised, washed with the sodium phosphate buffer described above, cut in $2 \mathrm{~mm}$ wide rings and immersed in a fixative solution containing $2.5 \%(\mathrm{vol} / \mathrm{vol})$ glutaraldehyde in $0 \cdot 1 \mathrm{M}$ cacodylate buffer, $\mathrm{pH} 7 \cdot 2$ at $4^{\circ} \mathrm{C}$ for two hours. The postfixation was achieved for two hours in $0 \cdot 1 \mathrm{M}$ cacodylate buffer $\mathrm{pH} 7.2$ containing $1 \% \mathrm{O}_{\mathrm{S}} \mathrm{O}_{4}(\mathrm{vol} /$ vol).

In a control series, the guinea pig ileal loops were washed with $1 \mathrm{mM}$ EDTA in $0.1 \mathrm{M}$ phosphate buffer $\mathrm{pH} 7.4$ containing $0.15 \mathrm{NaCl}$ and $1 \mathrm{mM}$ EDTA was added to the [ $\left.{ }^{125} \mathrm{I}\right]-\mathrm{IF}-\mathrm{Cbl}$ complex solution which was instilled. The incubation time of these control experiments was two hours. In another control series, the guinea pig ileal loops were instilled consecutively with $1 \mathrm{nmol}$ unlabelled saturated IF and $10.02 \mathrm{nmol}$ of iodinated IF-Cbl complex. The incubation time was 15 minutes.

\section{RADIOAUTOGRAPHIC METHOD}

After embedding in Epon, thin sections were taken and processed for radioautographic treatment as previously described. ${ }^{1516}$ The sections were coated with an emulsion (Ilford L4 nuclear emulsion diluted $1: 4$ with distilled water) and exposed from four to 10 weeks at $4^{\circ} \mathrm{C}$ and developed in Microdol X (Kodak) for four minutes at $17^{\circ} \mathrm{C}$ or in phenidon developer for two minutes at $20^{\circ} \mathrm{C}$. The sections were examined on a TEM Siemens 102 .

\section{Quantitative analysis}

Three kinds of analyses were done by counting a total of 11000 grains:

\section{(1) Frequence of the grains overlying the epithelium}

The scoring of the silver grains was carried out directly on the TEM screen at a magnification of $6000 /$ unit of membrane length, determined by the photographic 'square'. The length of each unit was estimated to $13.3 \mu \mathrm{m}$ using latex calibrated beads. The frequence was calculated from grain counting over $3 \times 1000 \mu \mathrm{m}$ of epithelium length for each ileal fragment. The results were expressed as the number of grains $/ 80 \mu \mathrm{m}$ length of epithelium.

\section{(2) Distribution of silver grains over the cellular} compartments

The silver grain distribution through the epithelial cells compartments was analysed directly on the TEM screen at a magnification of 6000 using the 'simple grain density procedure' of Ross and Benditt. ${ }^{17}$ Four compartments were determined in

Fig. 2 Silver grain distribution of the iodinated intrinsic factor cobalamin complex over the ileal epithelium after instillation of the tracer in vivo for 15 minutes $(0 \cdot 35 \mu \mathrm{Ci})$. (a) The radioautographs showed a restricted number of binding sites of the tracer on the apical microvillous membrane $(M V)$. The iodinated intrinsic factor was also present in the apical cytoplasm (Ap Cyt). No radioactivity was observed over the migrating cells $(M C)$. (b) At a higher magnification, the tracer detected over the brush border was mainly located in the intermicrovillous pits. (c) High magnification showed the association of the silver grains with small apical vesicles $(\mathrm{V})$. The apical vesicles were rare, (a) $\times 6000$, bar $=1 \mu \mathrm{m}$; (b) $\times 30000$, bar $=0 \cdot 2 \mu \mathrm{m}$;

(c) $\times 55000$, bar $=0 \cdot 2 \mu \mathrm{m}$. (Original magnifications) 

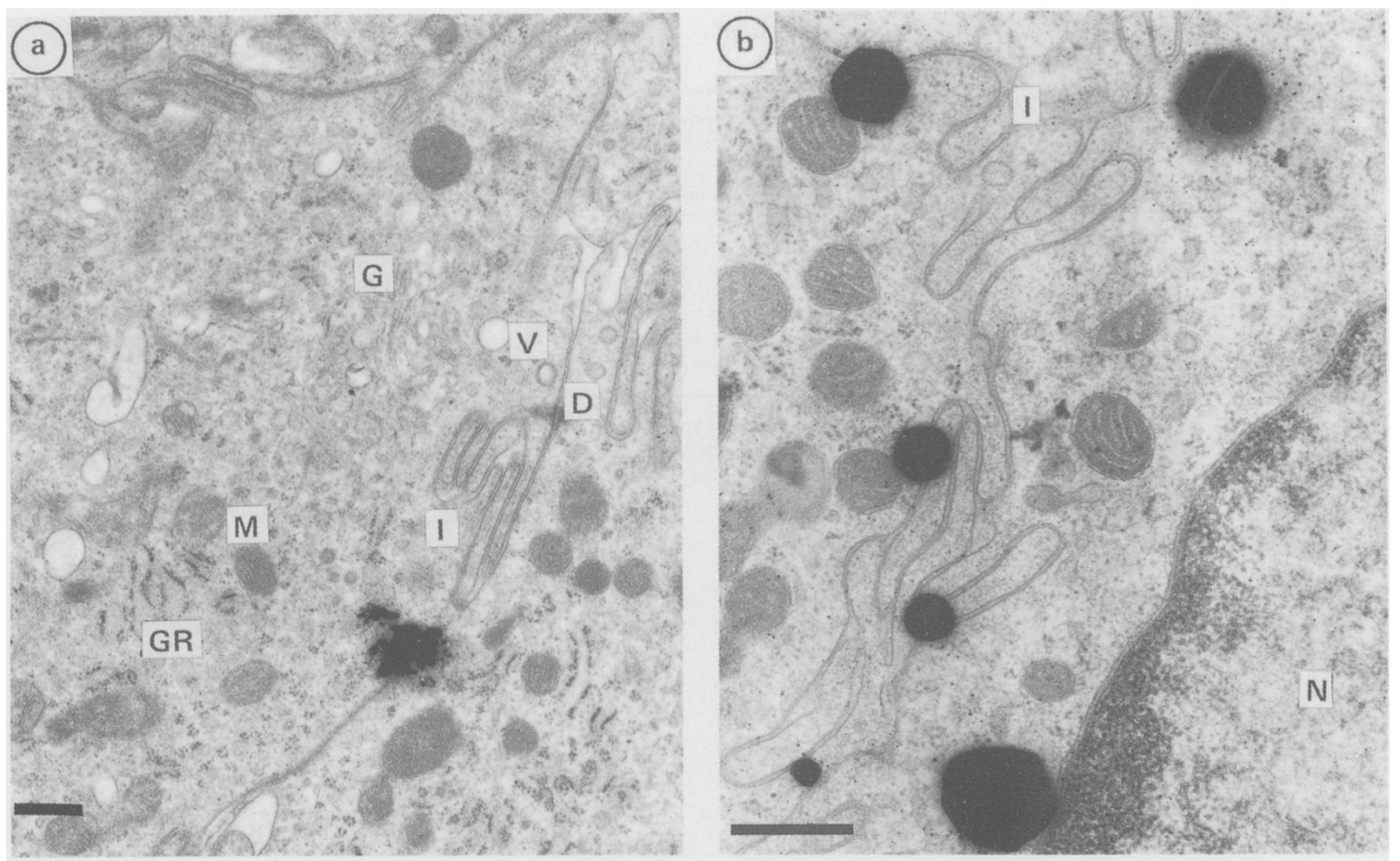

Fig. 3 Silver grains association with the infoldings of the lateral plasma membrane of ileal enterocytes after instillation of [ ${ }^{125}$ I]-IF-Cbl complex $(0.35 \mu \mathrm{Ci})$ in vivo in guinea pig ileum for $15 \mathrm{~min}$. (a) Clusters of grains overlying the lateral membrane. The cytoplasmic organelles did not exhibit any labelling ( $G=$ Golgi apparatus, $M=$ mitochondria, $R=$ endoplasmic reticulum, $V=$ vesicles, $D=$ desmosomes). (b) At a higher magnification, the grains were located at less than $1 \mathrm{HD}$ of the lateral plasma membrane $(N=$ Noyau $)$. (a) $\times 12000$, bar $=0.5 \mu \mathrm{m} ;(\mathrm{b}) \times 28100$, bar $=0.5 \mu \mathrm{m}$. (Original magnifications)

the epithelium and their respective area ratio were estimated on 20 cells micrographs using a digitising table (Hewlett Packard) connected to a computer Tektronik 4.

The relative area of the plasma membrane (including microvilli and intermicrovillous pits), the apical cytoplasm (between the plasma membrane and the nucleus midline), the basal cytoplasm (between the nucleus midline and the basal membrane) and the nuclcus were estimated to $0 \cdot 11,0 \cdot 44,0 \cdot 35$, and $0 \cdot 10$ respectively.

Each developed grain lying in a compartment was tabulated until a total of 200 grains/section three counts corresponding to 600 grains were performed per analysed ileal fragment. The results were presented as average number of grains per unit area of the compartment.

\section{(3) Relation between silver grains and apical specific} organelles

At higher magnifications, we often observed a proximity of silver grains with the mitochondria, the lateral membranes and the vesicles. This led us to determine whether or not these structures were associated to the silver grains using a half distance analysis.

Micrographs were taken at an initial magnification of $15000,20000,30000$. The negatives were then viewed in a microfilm reader projector with an enlargement of $\times 4$. Establishing a half distance (HD) of $90 \mathrm{nmol},{ }^{18}$ each silver grain was centred in a resolution boundary circle of a radius equivalent to one HD up to $5 \mathrm{HD}$. The organelles located in this area have been considered to be associated to the silver grain centring this circle. Each analysis was done over $3000 \mu \mathrm{m}$ length of epithelium.

\section{Results}

The human IF-Cbl complex was iodinated with a yield of about $18 \%$ and a specific radioactivity of $0 \cdot 18$ $\mu \mathrm{Ci} / \mu \mathrm{g}$. The [ $\left.{ }^{125} \mathrm{I}\right]-\mathrm{IF}-\mathrm{Cbl}$ complex was eluted with an apparent molecular mass of 50000 daltons in Sephacryl S 300 gel filtration (Fig. 1). It focused in four peaks isoelectric at $\mathrm{pH} 4 \cdot 6,4 \cdot 7,5 \cdot 0$, and $5 \cdot 1$ in isoelectrofocusing. The iodinated molecule was bio- 


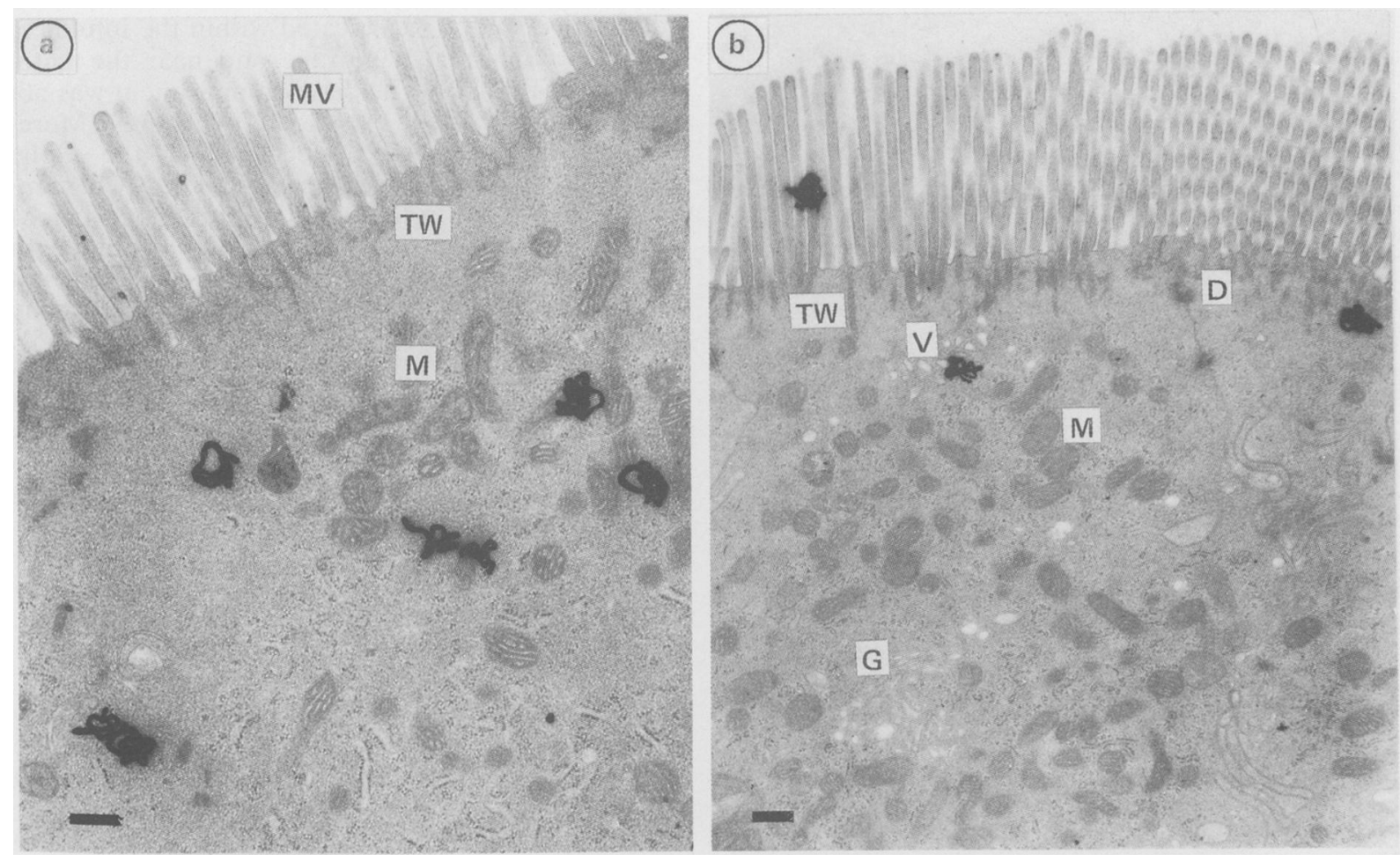

Fig. 4 (a) After two hours of instillation of the iodinated intrinsic factor cobalamin complex in guinea pig ileum (0.35 $\mu$ Ci), the grains are located very often near the numerous mitochondria $(M)$ of the apical cytoplasm. (b) Some grains were detected close to vesicular structures $(V)$ below the terminal web $(T W)$. The golgi apparatus $(G)$ did not exhibit any labelling.

(a) $\times 15000$, bar $=0.5 \mu \mathrm{m}$; (b) $\times 12000$, bar $=0.5 \mu \mathrm{m}$. (Original magnifications)

logically active since (i) it crossreacted in vitro with the guinea pig solubilised ileal receptor as shown by elution of the iodinated IF-receptor complex in the same position as dextran blue 2000 in Sephacryl gel filtration (Fig. 1). (ii) The binding of IF to the receptor did not occur in vitro in presence of $1 \mathrm{mM}$ EDTA (Fig. 1). (iii) The absorption of $\mathrm{CN}\left[{ }^{57} \mathrm{Co}\right] \mathrm{Cbl}$ tested by a Schilling test was significantly enhanced from $0.2 \%$ up to $10 \%$ when the labelled $\mathrm{Cbl}$ was ingested by an Addison-Biermer anaemia patient in presence of $10 \mu \mathrm{g}$ non-radioactive iodinated human IF. The iodination of either unsaturated human IF or saturated hog IF by a same procedure resulted in a significant loss of their biological activity. The iodinated IF was not degraded when incubated with intestinal juice of guinea pig as no change of its elution position in gel filtration nor liberation of iodine were observed.

In electron microscopy radioautography, the grains were observed in enterocytes but not in mucus secreting cells nor migrating cells (Fig. 2a). The grains overlying the microvilli compartment were mainly located over intermicrovillous pits (Fig. 2b).
This labelling was enhanced from $2 \cdot 7(0 \cdot 2)$ grains/80 $\mu \mathrm{m}$ length of epithelium up to $9 \cdot 4(1 \cdot 7)$ grains after respectively 15 minutes and two hours of delay (Table 1). After 15 minutes, some grains were

Table 2 Half distance (HD) analysis of iodinated intrinsic factor-cobalamin detected near or over mitochondria, vesicles, and lateral membrane of the apical compartment of enterocytes in radioautographs of guinea pig ileum

\begin{tabular}{|c|c|c|c|c|c|c|}
\hline \multirow[b]{3}{*}{$\begin{array}{l}H D \\
(n)\end{array}$} & \multicolumn{6}{|c|}{ Score of grains* } \\
\hline & \multicolumn{3}{|l|}{$15 \min$} & \multicolumn{3}{|l|}{$120 \mathrm{~min}$} \\
\hline & $\begin{array}{l}\text { Mito- } \\
\text { chondria }\end{array}$ & Vesicles & $\begin{array}{l}\text { Lateral } \\
\text { membrane }\end{array}$ & $\begin{array}{l}\text { Mito- } \\
\text { chondria }\end{array}$ & Vesicles & $\begin{array}{l}\text { Lateral } \\
\text { membrane }\end{array}$ \\
\hline 1 & 0 & 2 & 47 & 18 & 6 & 61 \\
\hline 2 & 2 & 2 & 18 & 8 & 8 & 33 \\
\hline 3 & 12 & 12 & 12 & 16 & 26 & 32 \\
\hline 4 & 14 & 16 & 16 & 28 & 32 & 17 \\
\hline 5 & 16 & 17 & 11 & 41 & 34 & 25 \\
\hline
\end{tabular}

*The score of grains corresponded to the number of silver grains which could be assigned to the cellular structure for a distance of 1-5 $\mathrm{HD}$ at a $\times 15(0) 0-\times 30(0)(0)$ magnification according to Salpeter et al." 


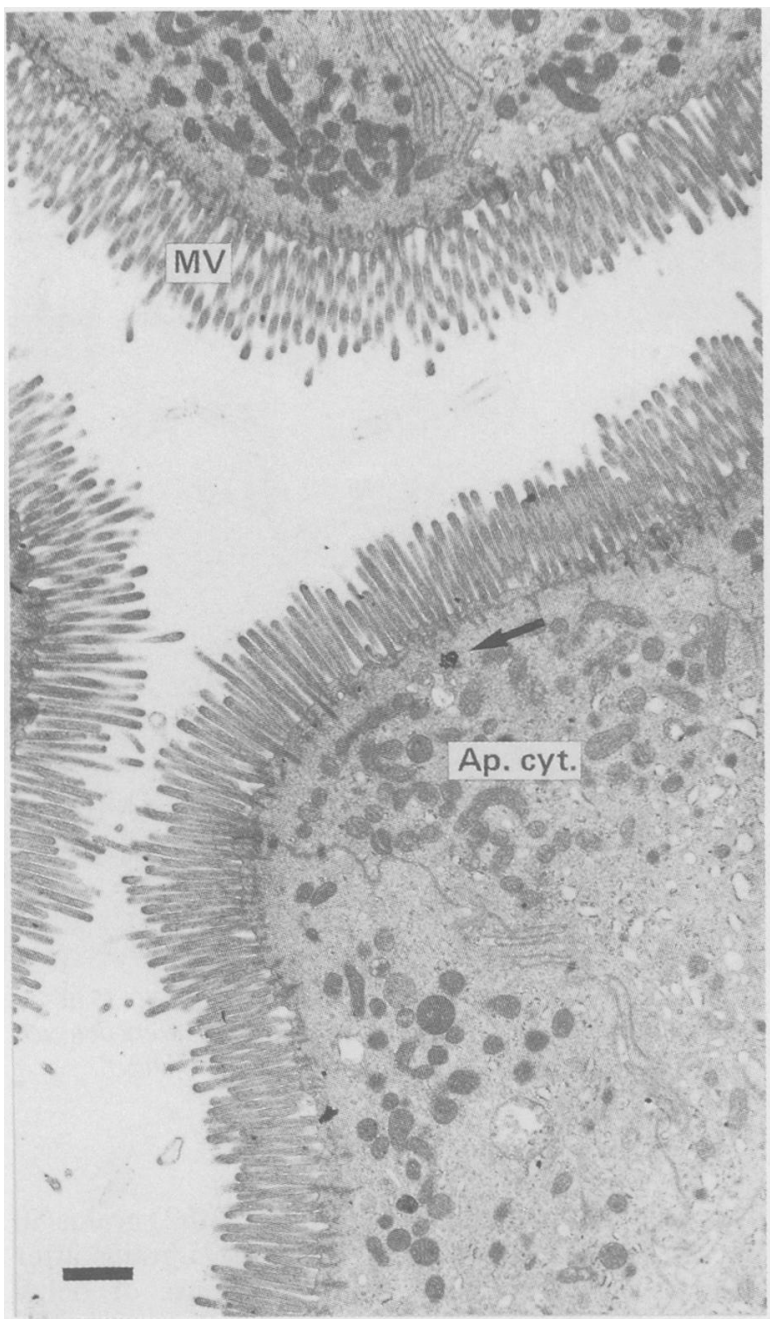

Fig. 5 A striking decrease of the labelling of the ileal epithelium was observed after instillation of the iodinated intrinsic factor cobalamin complex $(0 \cdot 35 \mu \mathrm{Ci})$ for two hours in presence of EDTA. The ultrastructure of the microvilli $(M V)$ was not modified, the internalisation of the tracer (arrow) in the apical cytoplasm (Ap Cyt) was about five-fold lower than that observed without EDTA $\times 6000$, bar $=1 \mu \mathrm{m}$. (Original magnification)

observed over the infolds of the lateral membrane of the supra nuclear compartment of enterocytes (Figs $3 a, b)$. The tracer entered the cells and was predominantly located in the apical cytoplasm compartment after two hours as well as after 15 minutes (Table 1). The grains were often found close to the numerous mitochondria located in this compartment and to tubulovesicular structures (about $100 \mathrm{~nm}$ diameter) under the terminal web (Figs 2c, 4a, 4b). The detailed study using HD analysis showed that the radioactive source was located within the infolds of the lateral plasma membrane and near the mitochondria (Table 2). The basal compartment was not significantly labelled, even after two hours. Moreover, no grains were detected over the Golgi apparatus (Fig. 4b). When the labelled IF-Cbl complex was instilled in the ileum in presence of $1 \mathrm{mM}$ EDTA, the number of grains counted/80 $\mu \mathrm{m}$ length of epithelium was significantly reduced but not abolished (Table 1). EDTA did not induce any disruption of the microvillous membrane (Fig. 5). When the iodinated IF-Cbl complex was instilled in presence of 50 fold its amount of unlabelled saturated IF, a $80 \%$ decrease of the frequency of grains overlying the epithelium was seen. The frequency of the intracellular labelling obtained when the iodinated IF-Cbl complex was instilled with phosphate buffer was similar to that observed using either Krebs buffer, intestinal juice, or bile (Table 1).

\section{Discussion}

The iodination procedure of IF did not induce any significant denaturation of the molecule as the physicochemical properties and the in vitro and in vivo biological activity were not modified. The iodination of the molecule was stable as (i) no liberation of [ $\left.{ }^{125} \mathrm{I}\right]$-iodine was observed in gel filtration, (ii) the radioactivity was not detected in the mucus secreting cells nor in migrating cells, (iii) the radioactivity which entered the enterocyte was much lower than that which remained in the lumen. Moreover, the intracellular distribution of grains was not uniform. Few grains were found in the nucleus and in the basal cytoplasm. This suggested that most of the grains detected in the cells corresponded to protein bound and not to free $\left[{ }^{125} \mathrm{I}\right]$-iodine.

The uptake of the [ $\left.{ }^{125} \mathrm{I}\right]-\mathrm{IF}-\mathrm{Cbl}$ complex was specific because it was significantly reduced either in presence of $1 \mathrm{mM}$ EDTA or in presence of unlabelled saturated IF and because it was observed only in enterocytes but never in mucus secreting cells. Contrary to the observation of Levine et $a l^{4}$ we did not observe any damage of the ileal epithelium in presence of $1 \mathrm{mM}$ EDTA (Fig. 5). EDTA inhibited the uptake of IF-Cbl rather by chelating the divalent cations than by disruption of the apical membrane. The discrepancy observed between our results and those of Levine et al was difficult to explain. In fact, the main difference between both in vivo experiments was the tissue fixation procedure. ${ }^{+}$The medium in which the $\left[{ }^{12} \mathrm{I}\right]-\mathrm{IF}-\mathrm{Cbl}$ complex was instilled (buffers, intestinal juice, or bile) seemed to not modify the internalisation of the complex. In the apical membrane, the IF-Cbl complex was very often seen in the intermicrovillous pits. The same result 
was described by Levine $e t a l,{ }^{4}$ who suggested that the IF receptor was located there. About $40-60 \%$ of the grains were detected in the apical cytoplasm compartment. It may, therefore, be assumed that IF enters the cell during $\mathrm{Cbl}$ absorption because the iodinated IF which was instilled was saturated with Cbl. Our results are in accordance with those of Kapadia et al who found biosynthetically labelled IF to the cytosol of enterocytes after incubating it with isolated ileal enterocytes. Internalisation of iodinated IF has also been shown using cell fractionation of guinea pig ileal mucosa. ${ }^{19}$ Levine et al, however, did not observe any intracellular IF using immunocytochemical localisation of IF in the guinea pig. ${ }^{4}$ In fact, these authors carefully noticed that the absence of internalisation of IF could be the consequence of either an inadequate penetration of the anti-IF antisera or a masking or a denaturation of the antigenic site of IF during the internalisation of the molecule.

The labelling of the cells was about $2 \cdot 5$ fold higher after two hours of delay than after 15 minutes. Moreover, the proportion of labelled IF localised on the microvilli increased from $33 \%$ to about $44 \%$. This result may correspond to a recycling of the iodinated IF in the microvillous membrane and could explain that everted sacs of guinea pig ileum would take up free $\left[{ }^{57} \mathrm{Co}\right] \mathrm{Cbl}$ after being previously incubated with IF-[ $\left.{ }^{57} \mathrm{Co}\right]-\mathrm{Cbl} .{ }^{10}$ Robertson and Gallagher had speculated that the IF receptor complex could be recycled because the uptake of cobalamin in the mouse was not modified after treatment of animals by cycloheximide, an inhibitor of protein synthesis, and because the animals recovered their capacity to take up $\mathrm{Cbl} 30$ minutes after ingestion of a saturation dose of the vitamin. ${ }^{201}$

Although our results provide evidence for internalisation of IF, it still remains to determine if this phenomenon corresponds to receptor mediated endocytosis. The concentration of labelled IF on the intermicrovilli pits of the apical membrane is compatible with such a mechanism. Some of the internalised labelled IF was found near or over very small vesicles at a high magnification. These vesicles cannot be definitely considered as endosomes because of the distance between them and the apical membrane. Moreover at the magnification used, we have not observed silver grains on coated pits nor on coated vesicles. This may correspond to a non-coated endocytosis but until now, the receptor bound protein has been shown to enter cells through coated pits and coated vesicles. ${ }^{22}$ In most of cellular protein internalisation, the endocytotic phase occurs very quickly, in less than 15 min. ${ }^{22}$ The longer delays used in our experiment cannot completely explain the absence of the tracer inendocytotic vesicles since the labelling of enterocytes increased in function of the duration of the experiment, showing that the labelled IF-Cbl complex was continuously internalised by the cells. The iodinated IF-Cbl complex detected in the apical cytoplasm was often localised near the mitochondria. The half distance analysis showed that some of the grains could be assigned to mitochondria for the 120 minutes experiments (Table 2). Such a localisation of the tracer could correspond to an interaction between IF-Cbl complex and the mitchondria as previously speculated. ${ }^{232}$ We have not seen any lysosomal localisation of the tracer. ${ }^{7}$ In fact, our experiment needs to be completed not only using short times of delay from 30 seconds up to 10 minutes but also using toxic agents as chloroquine.

Another remaining question was the significance of the presence of the tracer within the infolds of the lateral plasma membrane and within the small vesicles which were seen along this part of the lateral membrane. It seemed that IF was transported via small carrier vesicles to the lateral membrane. This may correspond rather to a transcytosis of the molecule from the lumen to the subepithelial tissue spaces and to the blood vessels than to a recycling of IF on the apical membrane. Such a mechanism has been already described for IgG in intestinal epithelial cells of newborn rats ${ }^{25}$ and for cationic ferritin in epithelial cells of the vas deferens of adult rats. ${ }^{26}$ In these examples, as well as in our experience, the tracer did not apparently originate directly from the apical membrane and the source of the small transcytotic vesicles remains to be determined.

The authors thank Dr J Khanfri for his contribution in the analysis of the plates, Mrs D Guillaume for typing the manuscript and Mrs Simonetti and Mrs F Fehrenbacher for excellent technical assistance. Institutional grants were received from the 'District Urbain de Nancy' and from the 'Fondation pour la Recherche Médicale'.

\section{References}

1 Donaldson RM, Small DM, Robins S, Mathan VI. Receptors for vitamin B-12 related to ileal surface area and absorptive capacity. Biochim Biophys Acta 1973; 311: 477-81.

2 Katz M, Cooper BA. Solubilized receptor for intrinsic factor vitamin B-12 complex from guinea pig intestinal mucosa. J Clin Invest 1974; 54: 733-9.

3 Hooper DC, Alpers DH, Burger RL, et al. Characterization of ileal vitamin B-12 binding using homogenous human and hog intrinsic factors. J Clin Invest 1973; 52: 3074-83.

4 Levine JS, Nakane PK, Allen RH. Immunocytochemical localization of intrinsic factor cobalamin factor bound to the guinea pig ileum in vivo. Gastroenterology 1982; 82: 284-90. 
5 Kapadia CR, Serfilippi D, Voloshin K, Donaldson RM Jr. Intrinsic factor-mediated absorption of cobalamin by guinea pig ileal cells. J Clin Invest 1983; 71: 440-8.

6 Jenkins WJ, Empson R, Jewell DP, Taylor KB. Subcellular localization of vitamin B12 during absorption in the guinea pig ileum. Gut 1981; 22: 617-22.

7 Horadagoda NU, Batt RM. Lysosomial localization of cobalamin during absorption by the ileum of the dog. Biochim Biophys Acta 1985; 838: 206-10.

8 Donaldson RM. How does cobalamin (vitamin B-12) enter and traverse the ileal cell. Gastroenterology 1985; 88: 1069-76.

9 Seetharam B, Presti M, Frank B, et al. Intestinal uptake and release of cobalamin complexed with rat intrinsic factor. Am J Physiol 1985; 248: 326-31.

10 Hines JD, Rosenberg A, Harris JW. Intrinsic factor mediated radio B-12 uptake in sequential incubation studies using everted sacs of guinea pig small intestine. Evidence that IF is not absorbed into the intestinal cell. Proc Soc Exp Biol Med 1968; 129: 653-8.

11 Gueant JL, Kouvonen I, Michalski JC, et al. Purification of human intrinsic factor using high performance ion exchange chromatography as the final step. FEBS Lett 1985; 184: 14-9.

12 Markwell MAK. A new solid-state reagent to iodinate proteins. I. Conditions for the efficient labeling of antiserum. Ann Biochem 1982; 125: 427-32.

13 Guéant JL, Djalali M, Aouadj R, et al. In vitro and in vivo evidence that the malabsorption of cobalamin is related to its binding on haptocorrin in chronic pancreatitis. Am J Clin Nutr 1986; 44: 265-77.

14 Kouvonen I, Gräsbeck R. Topology of the hog intrinsic factor receptor in the intestine. J Biol Chem 1981; 256 (1): 154-8.

15 Larra F, Droz B. Techniques radioautographiques et leur application à l'étude du renouvellement des constituants cellulaires. J Microscopie 1970; 9: 845.
16 Gérard A, Gérard H, Grignon G. In: Nagata T, ed. Radioautography data book. Tokyo IPC, 1982; 44-5: 377-8

17 Ross R. Benditt EP. Wound healing and collagen formation. Quantitative electron microscope radiautographic observations of proline-H utilization by fibroblasts. J Cell Biol 1965; $27: 83$.

18 Salpeter MM, McHenry FA. Salpeter EE. Resolution in electron microscope autoradiography. IV. Application to analysis of autoradiographs. J Cell Biol 1978; 76: 127.

19 Sheperd HA, Priddle J, Jenkins WJ, Jewell DP. Subcellular localization of ['25] intrinsic factor (IF) and $\left[{ }^{57} \mathrm{Co}\right]$ cyanocobalamin $\left({ }^{57} \mathrm{CoB} 12\right)$ during absorption by guinea-pig ileum [Abstract]. Gut 1982; 23: A911.

20 Robertson JA, Gallagher ND. In vivo evidence that cobalamin is absorbed by receptor mediated endocytosis in the mouse. Gastroenterology 1985; 89: 1353-9.

21 Robertson JA, Gallagher ND. Intrinsic factor. Cobalamin accumulates in the ilea of mice treated with chloroquine. Gastroenterology 1985; 89: 1353-9.

22 Goldstein JL, Anderson RGW, Brown MS. Coated pits, coated vesicles, and receptor-mediated endocytosis. Nature 1979; 279: 679-85.

23 Peters TJ, Hoffbrand AV. Absorption of vitamin B12 by the guinea pig. I. Subcellular localization of vitamin B12 in the ileal enterocyte during absorption. Br J Haematol 1970; 19: 369-82.

24 Rothenberg SP, Weisberg H, Ficarra A. Evidence for the absorption of immunoreactive intrinsic factor into the intestinal epithelial cell during vitamin B12 absorption. J Lab Clin Med 1972; 79: 587-97.

25 Abrahamson DR, Rodewald R. Evidence for the sorting of endocytotic vesicle contents during the receptor mediated transport of IgG across the newborn rat intestine. J Cell Biol 1981; 91: 270-80.

26 Hermo L, de Melo V. Endocytic apparatus and transcytosis in epithelial cells of the vas efferent in the rat. Anat Rec 1987; 217: 153-63. 